\title{
Transforming Growth Factor $\alpha$ : A Promoter of Motoneuron Survival of Potential Biological Relevance
}

\author{
Séverine Boillée, Josette Cadusseau, Muriel Coulpier, Gaël Grannec, and Marie-Pierre Junier \\ Institut National de la Santé et de la Recherche Médicale Unité 421, Faculté de Médecine, 94010 Créteil, France
}

Expression of transforming growth factor $\alpha$ (TGF $\alpha$ ), a member of the epidermal growth factor (EGF) family, is a general response of adult murine motoneurons to genetic and experimental lesions, TGF $\alpha$ appearing as an inducer of astrogliosis in these situations. Here we address the possibility that TGF $\alpha$ expression is not specific to pathological situations but may participate to the embryonic development of motoneurons. mRNA of TGF $\alpha$ and its receptor, the EGF receptor (EGFR), were detected by ribonuclease protection assay in the ventral part of the cervical spinal cord from embryonic day 12 (E12) until adult ages. Reverse transcription-PCR amplification of their transcripts from immunopurified E15 motoneurons, associated with in situ double-immunohistological assays, identified embryonic motoneurons as cellular sources of the TGF $\alpha$-EGFR couple. In vitro, TGF $\alpha$ promoted the survival of immunopurified E15 motoneurons in a dose-dependent manner, with a magnitude sim-

TGF $\alpha$ is one of the members of the epidermal growth factor (EGF) family, which share an EGF-like domain functioning as their receptor binding domain, and act through the erbB family of tyrosine kinase receptors (Hackel et al., 1999). This family can be subdivided into two groups according to the capability of the EGF-like factors to bind or not the EGF receptor (EGFR or erbB1) (Lee et al., 1995). TGF $\alpha$, the first member of the EGF family to have been discovered after EGF (Todaro et al., 1980), is one of the EGFR ligands that constitute the first group. Products of the neuregulin 1 gene are part of a second group of molecules that do not bind EGFR but do bind erbB3 and erbB4 and profoundly affect motoneuronal metabolism. They have been shown to be synthesized by embryonic motoneurons and to be necessary for proper motoneuronal maturation and, in particular, for the establishment of adequate interactions between the motoneuron and its glial and muscular environment (for review, see

Received Dec. 29, 2000; revised June 25, 2001; accepted June 29, 2001.

This research was supported by the Association Française Contre les Myopathies (a fellowship to S.B. and a grant to M.P.J.). We are grateful to Dr. Glenn T. Merlino for the generous donation of the transgenic mice used to breed for our experiments, Dr. Yin J. Ma for the design of the TGF $\alpha$ and EGFR PCR primers, and Dr. Larry E. Gentry for his generous gift of the antibody 1296. We thank Jean-Pierre Bellier for his participation to preliminary experiments and Dr. Marc Peschanski for critical reading of this manuscript.

Correspondence should be addressed to Marie-Pierre Junier at her present address: Institut National de la Santé et de la Recherche Médicale U114, Collège de France, 11 place Marcelin Berthelot, 75231 Paris cedex 05, France. E-mail: marie-pierre.junier@college-de-france.fr.

M. Coulpier's present address: Molecular Neurobiology, Department of Neurosciences, Karolinska Institute, S17177 Stockholm, Sweden.

Copyright (ㄷ) 2001 Society for Neuroscience $\quad 0270-6474 / 01 / 217079-10 \$ 15.00 / 0$ ilar to BDNF neuroprotective effects at equivalent concentrations. In a transgenic mouse expressing a human TGF $\alpha$ transgene under the control of the metallothionein 1 promoter, axotomy of the facial nerve provoked significantly less degeneration in the relevant motor pool of 1-week-old mice than in wild-type animals. No protection was observed in neonates, when the transgene exhibits only weak expression levels in the brainstem. In conclusion, our results point to TGF $\alpha$ as a physiologically relevant candidate for a neurotrophic role on developing motoneurons. Its expression by the embryonic motoneurons, which also synthesize its receptor, suggests that this chemokine is endowed with the capability to promote motoneuron survival in an autocrine-paracrine manner.

Key words: EGF; EGFR; erbB1; development; facial nucleus; spinal cord

Gassmann and Lemke, 1997; Burden, 1998). In contrast, links between members of the first EGF family group and motoneuronal metabolism have been established only under pathological conditions up to this day. Motoneuronal TGF $\alpha$ upregulation is thus the only example of enhanced synthesis of an EGF family factor by neuronal cells submitted to an aggression. It was found in wobbler mutant mice undergoing degeneration of their cervical spinal motoneurons, in muscle-deficient murine mutants affected by a degenerative process targeting their lumbar spinal motoneurons, and in hypoglossal motoneurons after axonal crush and cut (Junier et al., 1994, 1998; Lisovoski et al., 1997). The tightly correlated time courses of TGF $\alpha$ motoneuronal production with that of astrogliosis development and EGFR expression by reactive astrocytes designated these glial cells as TGF $\alpha$ primary targets. TGF $\alpha$ capability to induce astrogliosis when overexpressed in the CNS was subsequently demonstrated (Rabchevsky et al., 1998). Although TGF $\alpha$ expression was not observed in intact adult motoneurons, the possibility of an involvement of $\mathrm{TGF} \alpha$ in motoneuronal metabolism during development remains to be evaluated. The expression of several members of a given growth factor family by developing motoneurons (Elde et al., 1991; Schecterson and Bothwell, 1992; Krieglstein et al., 1998; Kanda et al., 1999; Garces et al., 2000) and of other EGF family members by immature motoneurons support such a possibility. We thus studied whether TGF $\alpha$ is expressed by embryonic motoneurons and sought for its possible function in the developing spinal cord. We report that embryonic motoneurons are cellular sources for both the factor and its receptor and show that TGF $\alpha$ has the capability to promote motoneurons survival during embryonic and early postnatal development. 


\section{MATERIALS AND METHODS}

Mice and rats were housed in an air-conditioned room with access to water and food ad libitum. Sprague Dawley rats (Janvier, Le Genest St. Isle, France) were used for experiments on embryos and motoneuron cultures. Mice were used to assay in vivo TGF $\alpha$ effects on motoneuronal survival. Metallothionein 1 (MT1)-hTGF $\alpha$ transgenic mice from the MT-42 line were a generous gift from Dr. G. Merlino of the National Cancer Institute (Bethesda, MD) and bred in our animal room. This transgenic line has been described in detail by Jhappan et al. (1990). It carries a 917 bp human TGF $\alpha$ cDNA under the control of the zincinducible mouse metallothionein 1 promoter. These transgenes have been obtained through injection of the construct directly into CD1 one-cell mouse embryos (Jhappan et al., 1990). Their age-matched controls corresponded to the parental CD1 strain (Charles River, SaintAubin les Elbeuf, France).

RNA extraction from tissue samples. Total RNA was obtained by the method of Chomczynski and Sacchi (1987) from the ventral part of the cervical spinal cord of embryonic day 12 (E12) to postnatal day 60 (P60) rats and the brainstem of postnatal mice. Pregnant females were anesthetized with chloral hydrate (400 mg/kg, i.p.), and the fetuses were retrieved surgically. A longitudinal incision was made dorsally from the neck to the tail of the fetus, and the spinal cord was removed and its ventral part was trimmed out after flattening the spinal cord on its ventral surface. The dorsal columns were discarded, and the ventral halves were collected. The entire length of the spinal cord was dissected out from E12 embryos. At all other embryonic ages and in postnatal animals, only the cervical part of the spinal cord was collected. Postnatal and adult animals received an overdose of pentobarbital (60 mg/kg, i.p.), and their cervical spinal cord was rapidly removed and the ventral part was dissected out as described above. For RNA extraction from the cervical spinal cords, the tissue samples were pooled before the extraction as follows: five animals per tube from E12-E21, four animals per tube from P2-P6, and three animals per tube from P14-P60. For brainstem collection, the mice were decapitated under pentobarbital anesthesia, the brains were rapidly removed, and the brainstem was dissected out under a binocular microscope. An anterior cut was made rostrally to the trapezoid bodies and a posterior cut rostrally to the lateral reticular nucleus. The resulting tissue piece encompassed the entire extent of the facial nuclei, and tissues from two different animals were pooled per tube. All tissues were immediately frozen on dry ice and stored at $-80 \mathrm{C}$ until further use.

Ribonuclease protection assay. The antisense TGF $\alpha$ cRNA probe used was obtained by in vitro transcription of a 400 bp EcoRI/HindIII cDNA fragment corresponding to the coding region of the rat $\mathrm{TGF} \alpha \mathrm{cDNA}$, subcloned into the pGEM3Z vector (Junier et al., 1991). The transcription was performed as described previously (Junier et al., 1991) in the presence of $\left[{ }^{32} \mathrm{P}\right] \mathrm{CTP}$. The template was linearized with EcoRI to obtain a 430 nucleotide (nt) [ $\left.{ }^{32} \mathrm{P}\right]$ CTP-labeled antisense RNA using SP6 RNA polymerase, 30 of the nucleotides corresponding to the vector multiple cloning site. The antisense EGFR RNA probe was derived from a $578 \mathrm{bp}$ Sau3A1 cDNA fragment of the rat EGFR cDNA (Petch et al., 1990), linearized with AvaII, and transcribed with T7 polymerase. Only $160 \mathrm{bp}$ of this cDNA fragment corresponds to the sequence of the extracellular domain of the full-length EGFR mRNA (Junier et al., 1993). The $169 \mathrm{nt}$ antisense cyclophilin probe was obtained from a Pst I/XmnI 111 bp fragment of the rat cyclophilin cDNA (Danielsson et al., 1988), subcloned into the pBluescript vector. The template, linearized with EcoRI and transcribed with T7 RNA polymerase, yielded a $169 \mathrm{nt}$ probe, 58 of which corresponding to the vector multiple cloning site. Levels of the mRNA of interest were assayed as described previously (Junier et al., 1991). Briefly, the tissue total RNA $(5 \mu \mathrm{g})$ was simultaneously hybridized to the antisense TGF $\alpha$ probe $(500,000 \mathrm{dpm})$ or the antisense EGFR probe and to the cyclophilin antisense RNA probe $(5000 \mathrm{dpm})$ to assess for procedural losses. Cyclophilin mRNA is expressed constitutively in brain tissue (Danielsson et al., 1988). The purified RNA-RNA duplexes were electrophoresed through a $7 \mathrm{M}$ urea-5\% acrylamide gel, and the gel was exposed to XAR-5 films for either $18 \mathrm{hr}$ (for cyclophilin signal analysis) or 4-8 d (for TGF $\alpha$ and EGFR signal analysis). Autoradiograms were analyzed by laser densitometry using the cyclophilin mRNA signal to standardize TGF $\alpha$ mRNA values. Results are expressed as the ratio of the TGF $\alpha$ mRNA signal to the cyclophilin mRNA signal.

Immunohistochemistry. E17 and E18 embryos were anesthetized on ice before being perfused transcardially with warm heparinized saline followed by $0.1 \mathrm{M}$ PBS, pH 7.4, containing $4 \%$ paraformaldehyde. The spinal cord was immediately removed and post-fixed for $4 \mathrm{hr}$ at $4^{\circ} \mathrm{C}$ in the same fixative. Tissues were frozen after a $24 \mathrm{hr}$ incubation in a $30 \%$ sucrose cryoprotective medium. Cryostat sections (10 $\mu \mathrm{m}$ thickness) were cut in the frontal plane. Immunohistochemistry was performed on sections mounted on gelatinized slides. The sections were incubated overnight at $4{ }^{\circ} \mathrm{C}$ in the appropriate dilution of the primary antibody in $0.05 \mathrm{M}$ Tris, $154 \mathrm{~mm} \mathrm{NaCl}, 0.02 \%$ BSA, and $0.3 \%$ Triton X-100, pH 7.5. Immunohistochemical detection was achieved using either the avidinbiotin complex immunoperoxidase technique and the diaminobenzidine chromogen (Vector Laboratories, Burlingame, CA) or the tyramide signal amplification system coupled to the fluorochrome cyanine $3(\mathrm{Cy} 3)$ or fluorescein (FITC; NEN, Paris, France). TGF $\alpha$-immunoreactive cells were identified with rabbit polyclonal antibody 1296 (1:5000), which recognizes a peptide sequence (amino acids 137-151) contained within the cytoplasmic domain of the TGF $\alpha$ precursor (pro-TGF $\alpha$ ) (Gentry et al., 1987). The use of an antiserum that recognizes the intracellular portion of the precursor ensured the identification of the cells that synthesize TGF $\alpha$ as opposed to cells susceptible to bind it. Adjacent sections were stained for the EGF receptor using the rabbit polyclonal antibodies 29.1 (1:250; Sigma, St. Quentin Fallavier, France) or sc-03 [1:100; Santa Cruz Biotechnology (Santa Cruz, CA) and Tebu (Le Perray en Yvelines, France)], which recognize a peptide sequence (amino acids 1005-1016) localized within the intracellular $C$ terminal tail of the EGFR. Alternate sections were stained for choline acetyltransferase (ChAT) using the goat polyclonal antibody AB144P [1:500; Chemicon (Temecula, CA) and Euromedex (Mundolsheim, France)]. Control experiments included omission of either the primary antiserum or the secondary antibody. Specificity of the pro-TGF $\alpha$ and EGFR antibodies in the nervous tissues, including preadsorption of the antibodies with their antigens, has been reported previously (Junier et al., 1991, 1994; Lisovoski et al., 1997; Rabchevsky et al., 1998). Immunofluorescence was observed with a fluorescent microscope (Axioplan 2; Zeiss, Le Pecq, France). Images were acquired on a Cool SNAP camera using the Cool SNAP software (Zeiss). For confocal immunofluorescence, slides were observed using a Zeiss LSM 410 confocal microscope. Two lasers were used depending on the fluorochrome. The excitation wavelengths were $543 \mathrm{~nm}$ for Cy3 and $488 \mathrm{~nm}$ for FITC, and the emission wavelengths were 570 and $510-525 \mathrm{~nm}$ for $\mathrm{Cy} 3$ and FITC, respectively. Tissue sections were observed with the $63 \times, 1.4$ numerical aperture lens (PlanApochromat; Zeiss, Oberkochen, Germany), the pinhole was set at 20, and the resolution on $x-y$ was of 0.2 and $0.7 \mu \mathrm{m}$ for $z$. Images were prepared for printing using Adobe Photoshop software (Adobe Systems, San Jose, CA).

Facial nerve cut. Cuts of the facial nerve were performed as described previously (Coulpier et al., 1996) on 2- and 8-d-old homozygous MT1hTGF $\alpha$ transgenic mice and their age-matched controls corresponding to the parental CD1 strain (Charles River). Animals were anesthetized on ice and subjected to a unilateral transection of the right facial nerve. The small branch that innervates the caudal auricular muscle and corresponds to motoneurons in the ventromedial part of the facial nucleus was sparred. The success of the axotomy was verified by the sagging of the right facial muscles before the animals were killed. Seven days after the operation, mice were killed and perfused with $4 \%$ paraformaldehyde as described above. Sections ( $30 \mu \mathrm{m}$ thick) of the brainstem were obtained throughout the entire extent of the facial nucleus and stained with cresyl violet. The nucleoli of the motoneurons were counted every 2 sections over the entire surface of the right and left facial nuclei in each animal. Results are expressed as percentage of total motoneurons counted in the left, unlesioned nucleus (mean \pm SEM). Statistical analysis was done using ANOVA, followed by a Fisher's test. Immunofluorescent detection of EGFR in the facial nucleus was performed as described previously. p75 NTR immunodetection was done using the rabbit polyclonal antip75 NTR antibodies (1:500; Promega, Madison, WI) and diaminobenzidine as a chromogen (Vector Laboratories). Counting of the numbers of $\mathrm{p} 75^{\mathrm{NTR}}$-immunoreactive motoneurons was performed and analyzed as described above.

Northern blot analysis. Total RNA (10 $\mu \mathrm{g} /$ lane) was size fractionated in agarose-formaldehyde gels and blotted onto nitrocellulose membranes. The hTGF $\alpha$ transgene and cyclophilin mRNAs were successively identified by hybridization to the following cDNA probes labeled using the random primer method and $\left[{ }^{32} \mathrm{P}\right] \mathrm{dCTP}: 316$ bp hTGF $\alpha$ cDNA fragment (Jhappan et al., 1990) and $1 \mathrm{~kb}$ rat cyclophilin cDNA (Danielsson et al., 1988). Signals were detected with a PhosphorImager (Molecular Dynamics, Orsay, France) and analyzed with the ImageQuant software (Molecular Dynamics) using the cyclophilin mRNA signal to standardize hTGF $\alpha$ mRNA values (Rabchevsky et al., 1998).

Motoneuron cultures. Cell suspensions of fetal motoneurons were pre- 
A

B

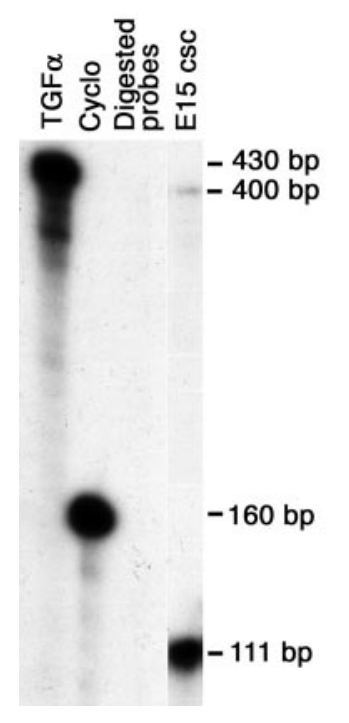

pared from 15-d-old rat fetuses as described previously (Camu and Henderson, 1992). Motoneurons were isolated and purified using the immunopanning method. The cells were first separated on a metrizamide gradient that segregates large cells. The motoneurons were then isolated using $192 \mathrm{IgG}$ attached previously to a substrate coated with anti-mouse antibodies. Determination of the neuronal enrichment of the cell suspension was performed on aliquots of the cell suspension smeared on a gelatin-coated glass slide. Immunohistochemical detection of the neuronal-specific microtubule-associated protein-2 (MAP-2) and of the motoneuronal-specific transcription factor islet-1 indicated a 92 and $96 \%$ enrichment in neurons, respectively, whereas only $2 \%$ of the cell suspension was immunolabeled with an antibody recognizing the astrocytespecific marker GFAP. Two thousand five hundred purified motoneurons were seeded in $100 \mu \mathrm{l}$ of serum-free L15 medium into 96-well plates coated previously with merosin $(2 \mu \mathrm{g} / \mathrm{ml}$; Life Technologies, Cergy Pontoise, France) as described previously (Hanson et al., 1998). One hour after plating, $100 \mu \mathrm{l}$ of L15 medium alone or containing rat synthetic TGF $\alpha(0.1-50 \mathrm{ng} / \mathrm{ml}$; Sigma) or recombinant human brainderived neurotrophic factor (BDNF) $(10 \mathrm{ng} / \mathrm{ml}$; Chemicon and Euromedex) was added to each well. Cultures were maintained at $37^{\circ} \mathrm{C}$ under a $5 \% \mathrm{CO}_{2}$ atmosphere for $3 \mathrm{~d}$. At that time, 88 and $87 \%$ of the cells corresponded to motoneurons, as assayed with islet-1/2 and ChAT immunoreactivity, respectively. The vast majority of the remaining cells displayed a neuronal morphology. The cells were then fixed with $4 \%$ paraformaldehyde and $0.1 \%$ glutaraldehyde in PBS. Immunolabeling with goat anti-ChAT antibody (1:200) was performed as described above using an initial 30 min blocking step in PBS containing $0.2 \%$ Triton $\mathrm{X}-100$ and $5 \%$ normal rabbit serum and diaminobenzidine as a chromogen. The number of motoneurons was determined over the entire culture dish area. Motoneurons had to exhibit ChAT immunoreactivity and at least three neurites with a length at least twice as long as the soma diameter to be included in the counts. Results are expressed as mean \pm SD motoneurons of three independent experiments. Statistical analysis were done using ANOVA, followed by a Fisher's test.

Reverse transcription-PCR amplification. Rat embryonic (E15) motoneurons were purified as described above, pelleted, and immediately frozen on dry ice. RNA was extracted from $10^{6}$ cells using Trizol following the instructions of the manufacturer (Life Technologies). After DNase digestion, $200 \mathrm{ng}$ of total RNA was reverse transcribed using oligo-dT as a primer and the Omniscript reverse transcriptase following the instructions of the manufacturer (Qiagen, Courtaboeuf, France). Substitution of RNA with $\mathrm{H}_{2} \mathrm{O}$ served as control of the reverse transcription (RT). PCR amplification was performed using the Taq polymerase from Life Technologies and the following primers: TGF $\alpha$ upper primer, TGG AGA ACA GCA CGT CC; TGF $\alpha$ lower primer, GCG CTG GGC TTC TCG TG; EGFR upper primer, GAG TCT AGA CAC CAG AGT GAT GTG TGG AG; and EGFR lower primer, GAG CTG CAG CGC TGG GGG TCT CGG GCC AT. The amplified cDNAs corresponded to nt $212-575$ of the rat TGF $\alpha$ cDNA and to nt $2863-3116$ of the rat EGFR
cDNA. PCR was done using a hot-start procedure and the following amplification program: $15 \mathrm{sec}$ at $94^{\circ} \mathrm{C}, 1 \mathrm{~min}$ at $55^{\circ} \mathrm{C}$, and $2 \mathrm{~min}$ at $72^{\circ} \mathrm{C}$, 35 cycles. PCR products were purified on a $2 \%$ agarose gel containing ethidium bromide before being transferred onto a Nytran membrane (Amersham Pharmacia Biotech, Orsay, France). The membranes were prehybridized for $4 \mathrm{hr}$ and hybridized overnight at $37^{\circ} \mathrm{C}$ with either a $\left[{ }^{32} \mathrm{P}\right] \mathrm{dCTP}$-labeled TGF $\alpha$ or $\left[{ }^{32} \mathrm{P}\right] \mathrm{dCTP}$-labeled EGFR cDNA probe $\left(10^{6} \mathrm{cpm} / \mathrm{ml}\right)$ corresponding to nt $1-400$ and nt $2863-3116$ of the TGF $\alpha$ and EGFR rat cDNAs, respectively. The prehybridization and hybridization solutions were composed of $50 \%$ formamide, $5 \times$ SSC, $25 \mathrm{~mm}$ $\mathrm{Na}_{2} \mathrm{HPO} 4, \mathrm{pH} 6.8,1 \times$ Denhardt's solution, $5 \%$ dextran sulfate, $1 \%$ SDS, and $20 \mu \mathrm{g} / \mathrm{ml}$ denaturated ssDNA. The membranes were washed twice for $15 \mathrm{~min}$ in $1 \times \mathrm{SSC}$ and $0.1 \%$ SDS at room temperature and twice in $0.25 \times$ SSC and $0.1 \%$ SDS at $37 \mathrm{C}$ for $15 \mathrm{~min}$ before be exposed to BIOMAX-MS Kodak films (Eastman Kodak, Rochester, NY).

\section{RESULTS}

\section{Developmental expression of TGF $\alpha$ and EGFR mRNA in the ventral horn of the rat cervical spinal cord}

TGF $\alpha$ mRNA levels were evaluated by ribonuclease protection assay at different developmental stages in the ventral part of the rat cervical spinal cord, in which motoneurons are located. Ribonuclease protection assay of TGF $\alpha$ and cyclophilin mRNAs yielded a 400 and 111 bp protected band, respectively (Fig. 1A). TGF $\alpha$ mRNA signal was detected at $12 \mathrm{~d}$ of gestation (E12), the earliest embryonic age examined. TGF $\alpha$ mRNA levels increased progressively throughout the gestation to reach adult levels at birth (Fig. 1B). Ribonuclease protection of the EGFR and cyclophilin mRNA yielded a 160 and $111 \mathrm{bp}$ protected band, respectively (Fig. $2 A$ ). Like TGF $\alpha$ mRNA, EGFR mRNA was detected in the spinal cord of E12 embryos. Its levels increased at subsequent embryonic ages and exhibited little variations up to the second week of postnatal life, before decreasing at 3 postnatal weeks (Fig. 2B).

\section{RT-PCR amplification of TGF $\alpha$ and EGFR transcripts from E15 immunopurified motoneurons}

To determine whether motoneurons could be one of the cellular sources of TGF $\alpha$ and/or EGFR mRNA detected by ribonuclease protection assay in the ventral spinal cord, RT-PCR amplification of TGF $\alpha$ and EGFR transcripts was performed on total RNA extracted from immunopurified E15 motoneurons. Immunohistochemical detection of the neuronal-specific protein MAP-2 and 
A

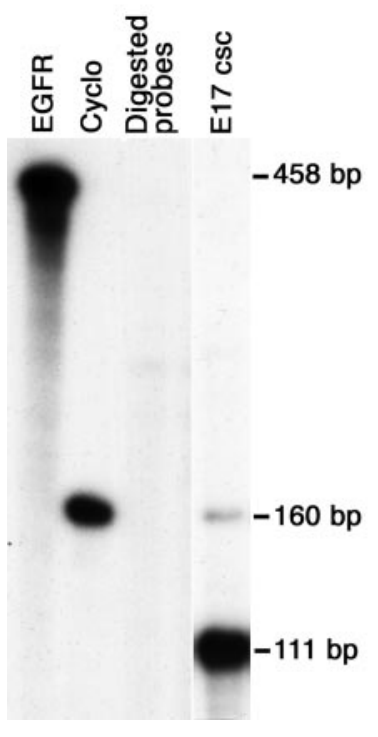

B

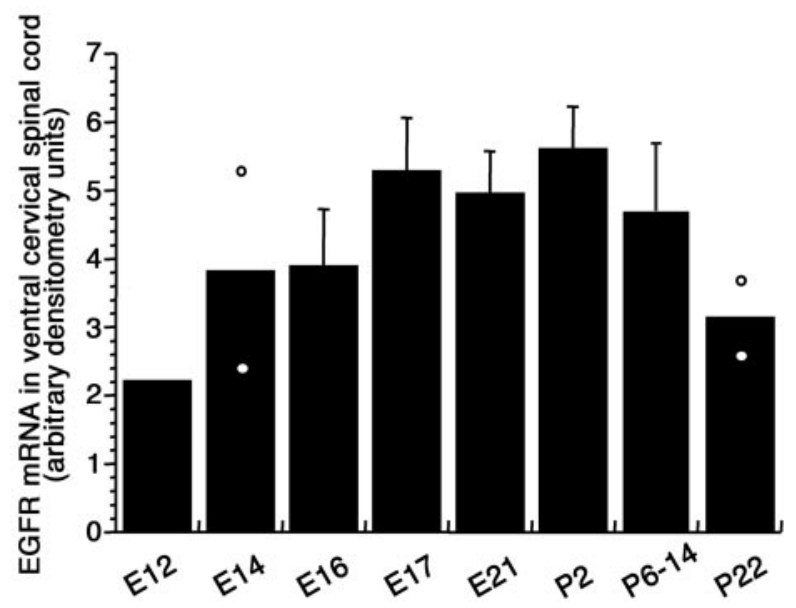

Figure 2. EGFR mRNA levels in the ventral horn of the cervical spinal cord. $A$, Autoradiogram of EGFR ribonuclease protection assay ( $8 \mathrm{~d}$ exposure, $5 \mu \mathrm{g} /$ lane total RNA). EGFR, Undigested EGFR cRNA probe; Cyclo, undigested cyclophilin cRNA probe; Digested probes, digested EGFR and cyclophilin cRNA probes; $E 17 \mathrm{csc}, 5 \mu \mathrm{g}$ of total RNA from the ventral horn of a E17 rat cervical spinal cord. $B$, Densitometric analysis of EGFR mRNA signals. Each point represents five (E12-E21), four (P2P6), and three (P14-P22) animals. Mean \pm $\mathrm{SD} ; n=3-5$.

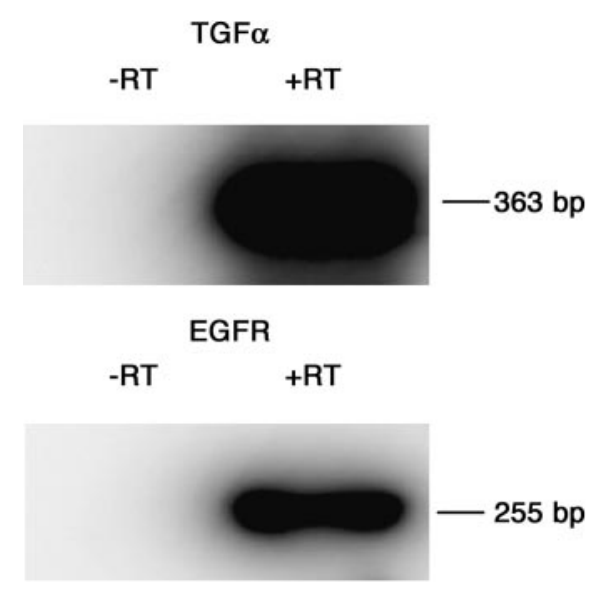

Figure 3. Southern blot hybridization of the RT-PCR amplification of the TGF $\alpha$ and EGFR transcripts from E15 purified motoneuron total RNA. The hybridization probes corresponded to the rat TGF $\alpha$ or the EGFR cDNA probes. $-R T$, The reverse transcriptase solution was omitted from the PCR reaction. $+R T$, PCR reaction in the presence of the reverse transcriptase solution.

of the motoneuronal-specific transcription factor islet-1 indicated a 92 and $96 \%$ enrichment in neurons, respectively, whereas only $2 \%$ of the cell suspension was immunolabeled with an antibody recognizing the astrocyte-specific marker GFAP. RT-PCR amplification yielded a 363 and $255 \mathrm{bp}$ band corresponding to the size expected for TGF $\alpha$ and EGFR cDNAs, respectively. The identity of the RT-PCR-derived products was verified through Southern blot hybridization with the rat TGF $\alpha$ and EGFR cDNA probes (Fig. 3).

\section{Cellular sources of pro-TGF $\alpha$ and its receptor in the embryonic rat cervical spinal cord}

Immunohistochemical procedures were used to verify the presence of TGF $\alpha$ and EGFR proteins in the cervical spinal cord and to identify their cellular sources in 17- and 18-d-old embryos. In the 17-d-old embryo, pro-TGF $\alpha$-immunoreactive cells were observed in the mediolateral and ventral parts of the spinal cord (Fig. $4 A$ ) in which motoneurons, identified by their immunore- activity for the motoneuron marker ChAT, were observed (Fig. $4 G)$. In addition, some pro-TGF $\alpha$-immunoreactive cells were gathered along the medial axis of the cervical spinal cord (data not shown). Fluorescent pro-TGF $\alpha$ immunohistochemistry yielded similar results in E18 spinal cord embryos. In the ventral part of the spinal cord, TGF $\alpha$-immunoreactive cells appeared as large-sized neurons (Fig. 4B, C). In the 17-d-old embryo, EGFRimmunoreactive cells displayed a localization similar to proTGF $\alpha$-immunoreactive cells (Fig. 4D). Fluorescent EGFR immunohistochemistry yielded similar results in E18 spinal cord embryos, EGFR-immunoreactive cells appearing as large-sized neurons in the ventral part of the spinal cord (Fig. $4 E, F$ ). Motoneuronal identity of the pro-TGF $\alpha$ - and EGFRimmunoreactive cells observed in the ventral horn of the embryonic spinal cord was further confirmed with doubleimmunofluorescent staining using either $\mathrm{TGF} \alpha$ and ChAT antibodies or EGFR and ChAT antibodies (Fig. 5). Confocal microscopy showed that neurons immunoreactive for TGF $\alpha$ were also immunoreactive for ChAT (Fig. 5A-C). ChAT immunolabeling appeared diffused throughout the cytoplasm (Fig. $5 A$ ), whereas TGF $\alpha$ immunostaining exhibited a punctated aspect (Fig. 5B). Likewise, EGFR-immunoreactive neurons were also ChAT immunoreactive (Fig. $5 D-F$ ), with the EGFR signal being preferentially localized at the plasma membrane (Fig. $5 E, F$ ).

\section{TGF $\alpha$ effects on embryonic rat motoneuron survival cultured in serum-free medium}

The observation of TGF $\alpha$ and EGFR expressing motoneurons during the period of developmental cell death led us to evaluate the effects of this growth factor on the survival of motoneurons immunopurified from E15 embryonic spinal cord. The percentage of motoneurons in the cellular preparation was assessed with the 4D5 monoclonal antibody, which recognizes the motoneuronspecific transcription factors islet-1/2 (Ericson et al., 1992), and with an anti-ChAT polyclonal antibody. The purification procedure yielded a 88 and $87 \%$ enrichment in motoneurons, as assayed with islet-1/2 and ChAT immunoreactivity, respectively. Motoneurons were seeded at low density in serum-free medium to avoid accumulation of motoneuron-derived growth factors and addition of EGF-like factors known to be abundant in serum. 

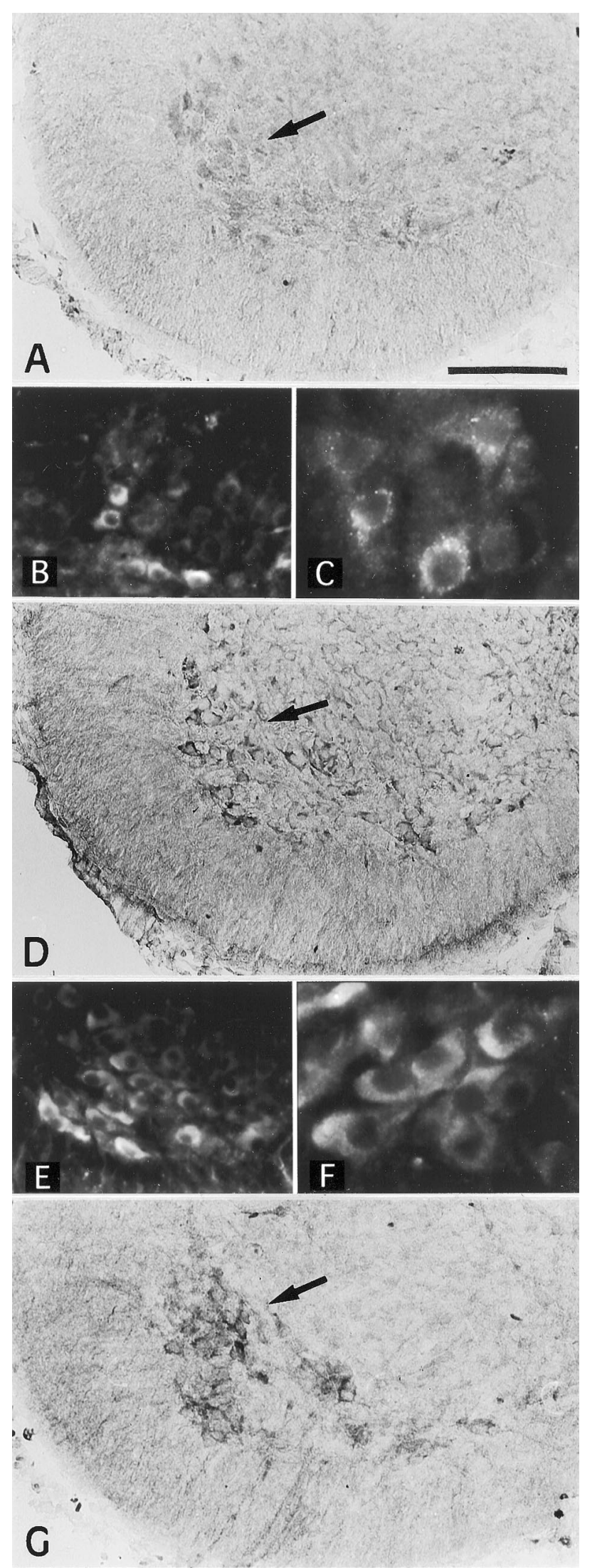

Figure 4. Immunohistochemical localization in the cervical spinal cord of 17- and 18-d-old rat embryos of the TGF $\alpha$ precursor, its receptor EGFR, and ChAT, a motoneuron marker. $A$, TGF $\alpha$ precursor immunolabeling in 17-d-old cervical spinal cord. The arrow points to some of the labeled cells in the ventral region of the spinal cord. $B, C$, Immunofluo-
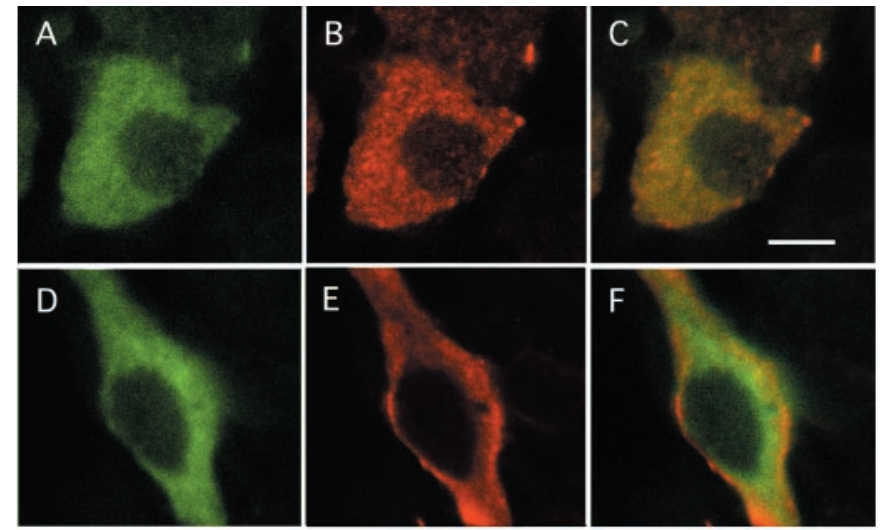

Figure 5. Confocal visualization of ChAT and TGF $\alpha$ precursor $(A-C)$ and of ChAT and EGFR $(D-F)$ immunofluorescent labelings in the ventral part of the cervical rat spinal cord of an 18-d-old embryo. TGF $\alpha$ precursor-immunoreactive neurons $(B)$ are also ChAT immunolabeled ( $A$ ). $C$, Overlay of ChAT (green) and TGF $\alpha$ (red) immunofluorescent signals depicted in $A$ and $B$. Likewise, EGFR-immunoreactive neurons $(E)$ are also ChAT immunoreactive $(D) . F$, Overlay of ChAT (green) and EGFR (red) immunofluorescent signals depicted in $D$ and $E$. Scale bar, $10 \mu \mathrm{m}$.

Motoneuronal survival was assessed after $3 \mathrm{~d}$ in culture. At that time, glia-like cells were rare (zero to five cells per well), including in the presence of TGF $\alpha$. Well developed ChATimmunoreactive cells displaying a large soma and at least three neurites with a length at least twice as long as the largest soma diameter were taken into account (Fig. 6). BDNF, a neurotrophin well known to be trophic for cultured embryonic motoneurons (Henderson et al., 1993), was used as a positive control. A statistically significant positive effect of TGF $\alpha$ was observed on motoneurons survival. TGF $\alpha$ promoted motoneurons survival within a concentration range of $0.1-50 \mathrm{ng} / \mathrm{ml}$, the maximal effect being observed at $50 \mathrm{ng} / \mathrm{ml}$, the highest concentration tested. At $10 \mathrm{ng} / \mathrm{ml}, \mathrm{TGF} \alpha$ effect on motoneuron survival was similar to the survival-promoting effect of $10 \mathrm{ng} / \mathrm{ml} \mathrm{BDNF}$ (Fig. 7).

\section{Axotomy-induced motoneuronal death in 1-week-old MT1-hTGF $\alpha$ mice}

The ability of TGF $\alpha$ to promote motoneuron survival in vivo was explored using the paradigm of facial nerve cut, which triggers motoneuronal death in young postnatal mice. Mice overexpressing an hTGF $\alpha$ transgene in the CNS were used. In this mouse strain, the transgene expression is under the control of the metallothionein 1 promoter. Because metallothionein 1 is expressed at barely detectable levels in embryonic and early postnatal ro-

rescent staining of the TGF $\alpha$ precursor in the ventralmost part of the cervical spinal cord gray matter of 18-d-old rat embryos at low $(B)$ and high $(C)$ magnifications. $D$, EGFR immunolabeling in 17-d-old cervical spinal cord. The arrow points to some of the EGFR-immunoreactive cells localized in the ventral portion of the spinal cord. $E, F$, Immunofluorescent staining in the ventralmost part of the cervical spinal cord gray matter of 18-d-old rat embryos of the EGFR at low $(E)$ and high $(F)$ magnifications. Note that EGFR-immunoreactive neurons appear more numerous in $E$ than TGF $\alpha$ precursor-immunoreactive neurons in $F$. $G$, ChAT immunohistochemical labeling. Immunolabeled neurons are localized in the mediolateral and ventral regions of the spinal cord in 17-d-old cervical spinal cord. The arrow points to some of the labeled cells in the ventral region of the spinal cord. In $B, C, E$, and $F$, the original immunofluorescent signal appeared red (cyanine 3 fluorochrome). Scale bar: $A$, $D, G, 150 \mu \mathrm{m} ; B, E, 140 \mu \mathrm{m} ; C, F, 56 \mu \mathrm{m}$. 


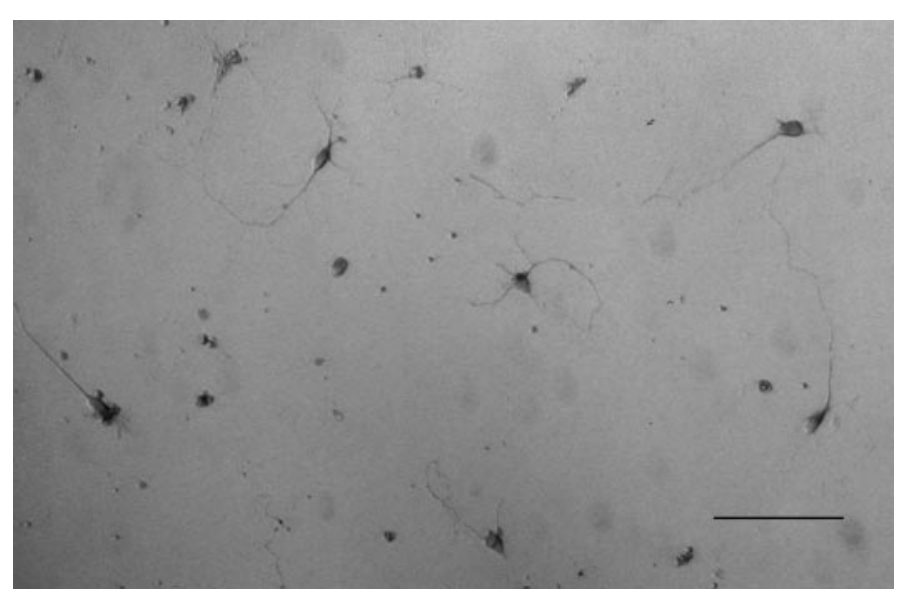

Figure 6. ChAT-immunoreactive neurons after $3 \mathrm{~d}$ in culture in the presence of $1 \mathrm{ng} / \mathrm{ml} \mathrm{TGF} \alpha$. Scale bar, $100 \mu \mathrm{m}$.

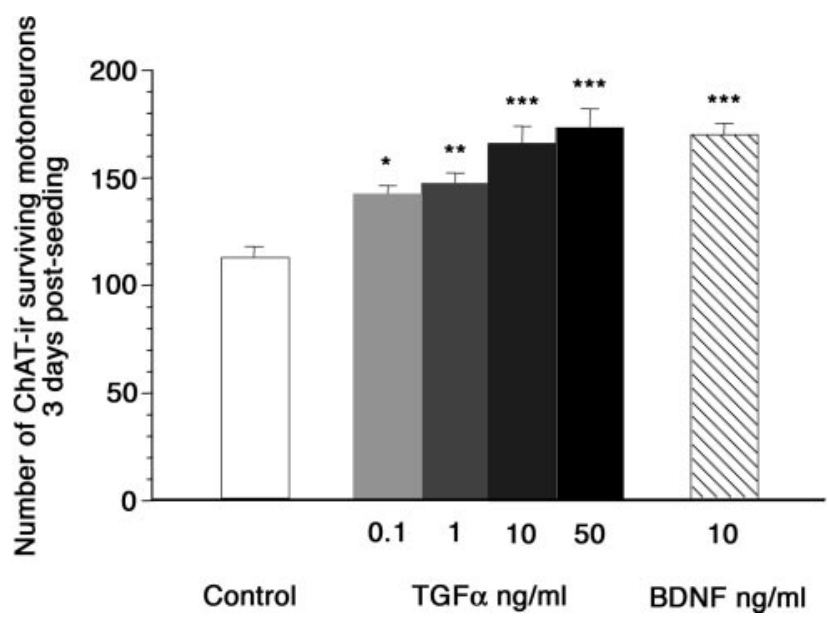

Figure 7. Effect of TGF $\alpha$ on spinal motoneuron survival. Number of motoneurons was determined after $3 \mathrm{~d}$ in culture in serum-free medium (white bar), in the presence of $0.1-50 \mathrm{ng} / \mathrm{ml} \mathrm{TGF} \alpha$ (gray and black bars), or in the presence of $10 \mathrm{ng} / \mathrm{ml} \mathrm{BDNF}$ (hatched bar). Cells were taken into account when exhibiting ChAT immunoreactivity and displaying a large soma and at least three neurites with a length at least twice as long as the largest soma diameter. The number of motoneurons was determined over the entire culture dish area. Means $\pm \mathrm{SD} ; n=7-10$; three independent experiments. ${ }^{*} p<0.005 ;{ }^{* *} p<0.0005$; ${ }^{* * *} \mathrm{p}<0.0001$; ANOVA followed by a Fisher's test.

dents brains (Waalkes and Klaassen, 1984; Choudhuri et al., 1996; Penkowa et al., 1999), hTGF $\alpha$ mRNA levels were first evaluated by Northern blot assays at 1,8 , and 15 postnatal days in the mid-brainstem, in which facial nuclei are localized (Fig. $8 A$, left). hTGF $\alpha$ mRNA levels were low at birth and increased through postnatal development to reach six times higher levels at postnatal day 15 , the oldest age examined (Fig. $8 A$, right). Vulnerability of facial motoneurons to axotomy-induced death has been reported to decrease with aging. It has been shown that axotomy induces death of $90 \%$ of the motoneurons in 2-d-old mice, of $50 \%$ in 1 -week-old mice, and of $10 \%$ in 2 -week-old mice (Kuzis et al., 1999). Facial nerve cuts were therefore performed on 8-d-old animals, a time at which half of the facial motoneurons is sensitive to axotomy-induced death and significant amounts of hTGF $\alpha$ mRNA are detected in the MT1-hTGF $\alpha$ transgenic mice brainstem. In addition, facial motoneuron response to axotomy was monitored in 2-d-old animals, a time at which the TGF $\alpha$
A.
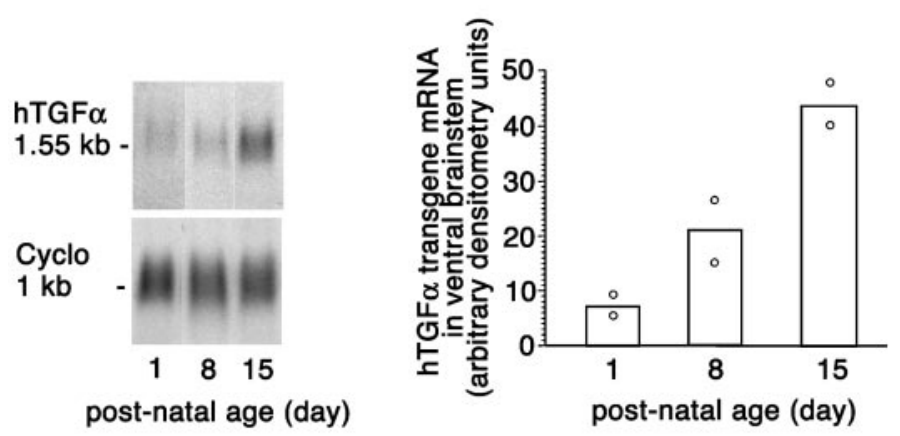

B.
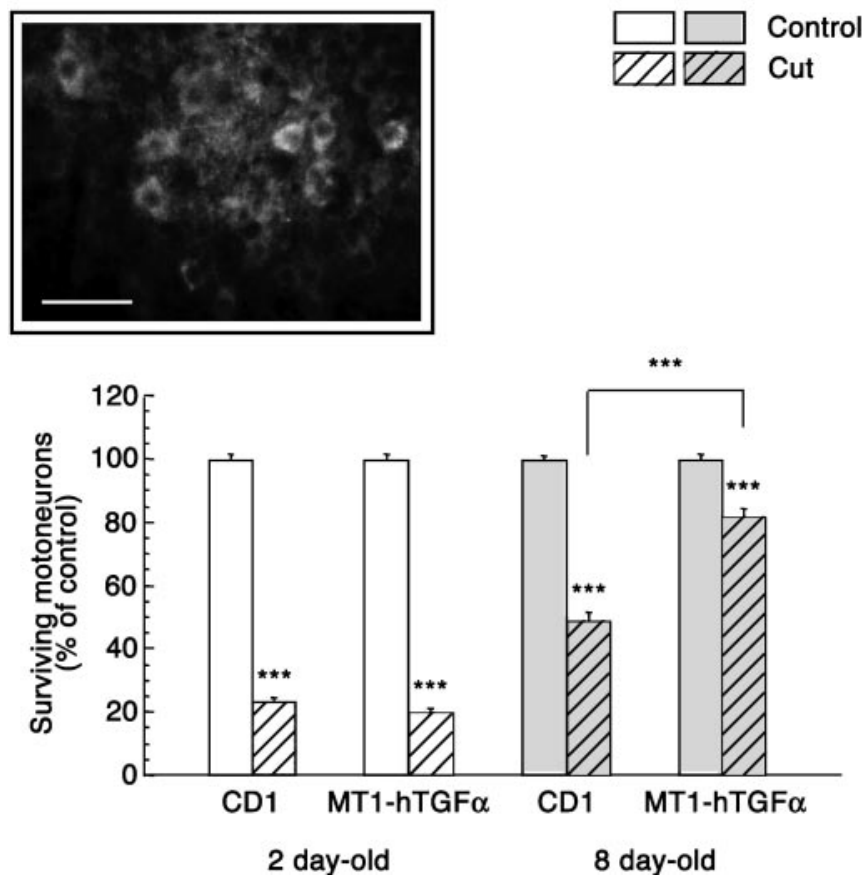

Figure 8. Effect of TGF $\alpha$ on axotomy-induced motoneuronal death in the facial nucleus of controls and MT1-hTGF $\alpha$ transgenic mice. $A$, Human TGF $\alpha$ transgene expression in the ventral brainstem of 1-, 8-, and 15-d-old MT1-hTGF $\alpha$ mice. Left, Northern blot analysis of hTGF $\alpha$ mRNA levels. Cyclophilin mRNA served as an internal standard. Right, Densitometric analysis of hTGF $\alpha$ mRNA signals. Note the increase in hTGF $\alpha$ mRNA levels as the animals age. Each point represents two animals. $B$, Quantification of facial motoneurons on the unlesioned and lesioned facial nuclei $7 \mathrm{~d}$ after lesion in control (CD1) and MT1-hTGF $\alpha$ transgenic mice operated at either 2 or $8 \mathrm{~d}$ of age. Results are represented as percentages of surviving motoneurons in the lesioned facial nucleus $7 \mathrm{~d}$ after axotomy relative to motoneuron numbers in the contralateral, unlesioned facial nucleus. Unhatched bars, Unlesioned nucleus. Hatched bars, Lesioned nucleus. Mean \pm SEM; $n=4$; ANOVA followed by the Fisher's test; ***p $<0.001$. Inset, Immunohistochemical localization of EGFR in the facial nucleus of 1-week-old MT1-hTGF $\alpha$ transgenic mice. Scale bar, $75 \mu \mathrm{m}$.

transgene is expressed at low levels. The examination of facial nuclei $7 \mathrm{~d}$ after the transection of the facial nerve at $2 \mathrm{~d}$ of age revealed a dramatic reduction in the number of neurons in control mice, and, as expected, similar observations were made in transgenic mice. Eighty percent of the facial motoneurons were lost 
(mean \pm SEM of motoneurons corresponding to $1377 \pm 28$ in intact nucleus vs $325 \pm 19$ in axotomized nucleus in control mice and $1367 \pm 25$ vs $273 \pm 19$ in transgenic mice; $n=4$ ) (Fig. $8 B$ ). Most surviving motoneurons were observed in the ventromedial part of the nucleus, which corresponds to the nonsectioned caudal auricular branch of the facial nerve. In 8-d-old control mice, axotomy also triggered facial motoneuron death $7 \mathrm{~d}$ after lesion but to a lesser extent than in 2-d-old animals. Fifty percent of the motoneurons were lost (mean \pm SEM of motoneurons corresponding to $1359 \pm 22$ in intact nucleus vs $666 \pm 39$ in axotomized nucleus in control mice; $n=4$ ) (Fig. $8 B$ ). In 8-d-old transgenic mice, surviving facial motoneurons observed $7 \mathrm{~d}$ after axotomy appeared more numerous than in control mice. Only $18 \%$ of the motoneurons were lost (mean \pm SEM of motoneurons corresponding to $1193 \pm 21$ in intact nucleus vs $978 \pm 33$ in axotomized nucleus; $n=4$ ) (Fig. $8 B$ ). Observation of numerous EGFR-immunoreactive motoneurons in the facial nucleus of these mice indicated that these cells are endowed with the capability to be directly affected by TGF $\alpha$ (Fig. $8 B$, inset). Such a low percentage of motoneurons death observed after the axotomy of the facial nerve of 8 -d-old transgenic mice is, in control mice, attained only when the axotomy is performed after 2 weeks of postnatal life (Kuzis et al., 1999). The possibility, nevertheless, remained that motoneuron protection observed in the 8-d-old transgenic mice resulted from an accelerated maturation of the facial motoneurons. To address this possibility, motoneuronal expression of the low-affinity neurotrophin receptor $\mathrm{p} 75^{\mathrm{NTR}}$ was used as an index of motoneuron maturation in the intact facial nucleus. p $75^{\mathrm{NTR}}$ motoneuronal expression is indeed known to decrease progressively during the first 2 weeks of postnatal life before disappearing in the adults (Eckenstein, 1988; Yan and Johnson, 1988; Ernfors et al., 1989). The numbers of p75 NTR immunoreactive motoneurons in 2-week-old transgenes and controls were similar and represented $2.4-3.4 \%$ of the population of facial motoneurons (control mice $32 \pm 9.5$ vs transgenic mice $40.7 \pm 6.6$ p $75^{\text {NTR }}$-immunoreactive motoneurons; mean $\pm \mathrm{SEM}$; $n=3)$. In 1-week-old transgenes, $\mathrm{p} 75^{\mathrm{NTR}}$-immunoreactive facial motoneurons were 4.4 times more numerous than in 2-week-old control animals but represented only $10.4 \%$ of the population of facial motoneurons instead of $16.2 \%$ in 1-week-old controls (transgenic mice $142.3 \pm 5.7$ vs control mice $223 \pm 14.5$; mean \pm $\mathrm{SEM} ; n=3 ; p=0.0001)$.

\section{DISCUSSION}

Studies over the past 8 years have revealed that developing motoneurons synthesize at least one class of the EGF family of growth factors, the neuregulin 1 gene products. Our results show that, in rat embryonic motoneurons, this family extends to TGF $\alpha$. They also indicate that this expression might have functional consequences by providing evidences in vitro and in vivo of a role for $\mathrm{TGF} \alpha$ as a promoter of motoneuron survival.

\section{A functional autocrine-paracrine loop indicated by TGF $\alpha$ and EGFR coexpression}

Localization of $\mathrm{TGF} \alpha$ in embryonic nervous tissues is only known in the forebrain (Kornblum et al., 1997). Our results show that TGF $\alpha$ and EGFR transcripts can be detected in the rat spinal cord from 12 d postcoitum until adult ages. Most cells immunoreactive for the TGF $\alpha$ precursor and its receptor were localized in the ventral and mediolateral part of the cervical spinal cord. This distribution matches that observed for motoneurons identified by their ChAT immunoreactivity and their large soma size (Altman and Bayer, 1985; Phelps et al., 1990). Double-immunohistological assays showing that pro-TGF $\alpha$ - and EGFR-immunoreactive cells are indeed ChAT immunoreactive, associated with RT-PCR amplification of the TGF $\alpha$ and EGFR transcripts from suspensions of purified motoneurons containing at most $2 \%$ of GFAPimmunoreactive cells, confirmed motoneurons as cellular sources of the TGF $\alpha$-EGFR couple.

\section{TGF $\alpha$ promotes motoneuron survival}

TGF $\alpha$ and EGFR coexpression in embryonic motoneurons during the period of developmental cell death raised the possibility that TGF $\alpha$ affects regulation of neuronal survival through an autocrine-paracrine mode of action. The increase in motoneuron survival observed in culture in the presence of TGF $\alpha$ indicates that this factor has the capability to promote survival of embryonic motoneurons, an observation similar to that reported by Hanson et al. (1998) with a single $\mathrm{TGF} \alpha$ concentration of 50 $\mathrm{ng} / \mathrm{ml}$. TGF $\alpha$ effect is dose dependent and, at the highest concentrations, similar in magnitude to the survival stimulatory effect of equivalent concentrations of BDNF in our culture conditions. EGFR expression by motoneurons and the lack of significant glial contamination in the cultures (zero to five cells per culture well, including in the presence of $\mathrm{TGF} \alpha$ ) indicate that astrocytes do not mediate TGF $\alpha$ effects on motoneurons. This singles out motoneurons among the neuronal populations known to be responsive to TGF $\alpha$ neurotrophic effects, which, up to this day, have been shown to occur in most cases through the astrocytes intermediacy (for review, see Junier, 2000).

TGF $\alpha$ is not the only growth factor endowed with the capability to act in an autocrine-paracrine manner on motoneurons. The growth factors $\mathrm{TGF} \beta_{2}$ and TGF $\beta_{3}$, as well as neurotrophin-3, are synthesized by embryonic motoneurons together with their receptor and promote embryonic motoneuronal survival (Flanders et al., 1991; Henderson et al., 1993; Gouin et al., 1996; Krieglstein et al., 1998). To examine whether TGF $\alpha$ promoting-survival action on motoneurons extends to in vivo situations, we used the paradigm of facial nerve cut in early postnatal mice. This model is widely used to test the ability of growth factors to promote motoneuron survival in situ (Houenou et al., 1994). In addition, axotomized motoneurons die in an apoptotic manner, as during physiological developmental death (de Bilbao et al., 2000; Vanderluit et al., 2000), and are protected by the same molecules (Sendtner et al., 1990, 1992; Yan et al., 1992, 1995; Henderson et al., 1993, 1994; Koliatsos et al., 1993; Dubois-Dauphin et al., 1994; Kato and Lindsay, 1994; Martinou et al., 1994; Farlie et al., 1995; Vejsada et al., 1995; Coulpier et al., 1996). In the MT1hTGF $\alpha$ mice, the transgene expression is driven by the metallothionein 1 promoter, and metallothionein 1 synthesis appears only during late postnatal development (Waalkes and Klaassen, 1984; Choudhuri et al., 1996; Penkowa et al., 1999). Accordingly, low amounts of the transgene were expressed in the midbrainstem of 2-d-old transgenic mice. In contrast, facial motoneurons are protected from axotomy-induced cell death in 1-weekold mice when expression of human TGF $\alpha$ transgene increases in the brainstem. Approximately $60-65 \%$ of the facial motoneurons disappearing in control mice are rescued from death in MT1hTGF $\alpha$ mice. The possibility exists that TGF $\alpha$ overexpression leads to an accelerated maturation of the motoneurons and, hence, to an enhanced resistance to the deleterious effects of axotomy. Although a reduced amount of p75 ${ }^{\text {NTR }}$-immunoreactive motoneurons was observed in the transgenic mice facial nucleus $(10 \%$ of the facial motoneuron population in 1-week-old 
transgenic mice vs $16 \%$ in age-matched controls), it is not sufficient to account for the increase in motoneuron survival observed in the transgenic mice. Hence, if accelerated motoneuronal maturation indeed occurs in these transgenic mice, it accounts only partly for the TGF $\alpha$ neuroprotective effects obtained in this in vivo model. In addition, detection of numerous EGFRimmunoreactive facial motoneurons in 1-week-old intact facial nucleus suggests that facial motoneurons can be directly affected by TGF $\alpha$. The possibility remains, however, that other EGFRexpressing cells, not clearly detectable in our assay, also mediate part of the TGF $\alpha$ neuroprotective effects. Altogether, the present results indicate that $\mathrm{TGF} \alpha$, like other factors trophic for motoneurons (Oppenheim, 1996; Sendtner et al., 1996), is available in situ in the developing spinal cord, its receptor is expressed by embryonic motoneurons, and its survival-promoting effects can be disclosed in both in vitro and in vivo assays. These data give credence to the existence of a biological relevant role of TGF $\alpha$ in motoneuronal development.

However, the extent of this biological relevance remains to be evaluated. Resolution of this issue depends in part on examination of mice lacking TGF $\alpha$ or its receptor. The EGFR null mice exhibit embryonic or early postnatal lethality depending on the genetic background, essentially as a result of placental or lung defects (Miettinen et al., 1995; Sibilia and Wagner, 1995; Threadgill et al., 1995). They display severe impairment of brain development (Threadgill et al., 1995; Kornblum et al., 1998; Sibilia et al., 1998), but alterations in motor nuclei have not been explored. In contrast, TGF $\alpha$ null mice develop normally (Luetteke et al., 1993; Mann et al., 1993), and the only CNS defect reported to date corresponds to the lack of a nigral dopaminergic subpopulation (Blum, 1998). To our knowledge, no exploration of the TGF $\alpha-/-$ motoneuronal systems has been undertaken. The absence of major CNS defect, at least at the clinical level, may stem from the existence of functional redundancies between the different EGFR ligands. Indeed, at least two other EGFR ligands, heparin-binding-EGF and amphiregulin, have been detected in the spinal cord (Hayase et al., 1998) (MPJ, unpublished results). It may also result from the existence of subtle interventions for TGF $\alpha$, the factor mediating in part the action of other promoters of motoneuron survival. Its absence would thus lead only to discreet functional modifications. Development of TGF $\alpha$ blocking antibodies should allow to definitely evaluate whether TGF $\alpha$ is physiologically involved in the control of motoneuron development.

\section{TGF $\alpha$ : another member of the EGF family to be expressed by embryonic motoneurons}

Our results show that embryonic motoneurons express another EGF family member in addition to neuregulin1. However, marked differences exist between these factors. Neuregulin1 ensures the adequate interactions between motoneurons and their environment. It affects Schwann cell metabolism at all stages of their development and the establishment of the neuromuscular junction, both Schwann and muscle cells expressing neuregulin1 receptors (Burden, 1998; Mirsky and Jessen, 1999). In contrast, our results indicate that the motoneurons themselves constitute TGF $\alpha$ targets in the embryo and that the factor fulfils a trophic role toward the motoneurons. An effect of TGF $\alpha$ on Schwann and muscle cells cannot, however, be excluded. Its receptor has been described in these cells that, at least in vitro, may be sensitive to its mitogenic and/or differentiative actions (Lim and Hauschka, 1984; Olwin and Hauschka, 1988; Toma et al., 1992; Sastry et al.,
1996; Halse et al., 1999). This, associated with the capability of the different EGF family members to interact through heterodimerizations of their respective receptors (Beerli and Hynes, 1996; Graus-Porta et al., 1997; Lenferink et al., 1998), allows interactions between neuregulin 1 and $\mathrm{TGF} \alpha$ to be envisioned. Another difference stems from the switch in TGF $\alpha$ cellular sources during development. Neuregulin1 products are synthesized by motoneurons throughout life (Chen et al., 1994) and, in the adult, participate to the maintenance of the neuromuscular junction (Sandrock et al., 1997). In contrast, TGF $\alpha$ source changes from motoneurons to white matter astrocytes and few small-sized neurons in mature animals. At this stage, TGF $\alpha$ motoneuronal expression may be observed only under pathological situations, and reactive astrocytes and Schwann cells constitute then its potential targets (Toma et al., 1992; Junier et al., 1994; Lisovoski et al., 1997). Inversely to TGF $\alpha$, motoneuronal neuregulin1 expression declines in adults after axotomy (Bermingham-McDonogh et al., 1997), suggesting that TGF $\alpha$ could compensate in part neuregulin1 loss.

\section{Conclusion}

Our results allow TGF $\alpha$ to be added to the list of growth factors capable of acting on developing motoneurons. It is now acknowledged that factors trophic for motoneurons may derive not only from their muscle targets but also from local sources (Oppenheim, 1996; deLapeyrière and Henderson, 1997). In this context, $\mathrm{TGF} \alpha$ appears as a putative autocrine-paracrine growth factor for motoneurons.

\section{REFERENCES}

Altman J, Bayer AB (1985) The development of the rat spinal cord. Advances in anatomy embryology and cell biology (Beck F, Hild W, van Limborgh J, Ortmann R, Pauly JE, Schiebler TH, eds). Springer, Berlin.

Beerli RR, Hynes NE (1996) Epidermal growth factor-related peptides activate distinct subsets of ErbB receptors and differ in their biological activities. J Biol Chem 271:6071-6076.

Bermingham-McDonogh O, Xu YT, Marchionni MA, Scherer SS (1997) Neuregulin expression in PNS neurons: isoforms and regulation by target interactions. Mol Cell Neurosci 10:184-195.

Blum M (1998) A null mutation in TGF-alpha leads to a reduction in midbrain dopaminergic neurons in the substantia nigra. Nat Neurosci 1:374-377.

Burden SJ (1998) The formation of neuromuscular synapses. Genes Dev $12: 133-148$

Camu W, Henderson CE (1992) Purification of embryonic rat motoneurons by panning on a monoclonal antibody to the low-affinity NGF receptor. J Neurosci Methods 44:59-70.

Chen MS, Bermingham-McDonogh O, Danethy Jr FT, Nolan C, Scherer SS, Lucas J, Gwynne D, Marchionni MA (1994) Expression of multiple neuregulin transcripts in postnatal rat brains. J Comp Neurol 349:389-400.

Chomczynski P, Sacchi N (1987) Single-step method of RNA extraction by acid guanidium thiocyanate-phenol-chloroform extraction. Anal Biochem 162:156-159.

Choudhuri S, Liu WL, Berman NE, Klaassen CD (1996) Cadmium accumulation and metallothionein expression in brain of mice at different stages of development. Toxicol Lett 84:127-133.

Coulpier M, Junier MP, Peschanski M, Dreyfus PA (1996) Bcl-2 sensitivity differentiates two pathways for motoneuronal death in the wobbler mutant mouse. J Neurosci 16:5897-5904.

Danielsson PE, Forss-Peter S, Brow MA, Calavetta L, Milner RJ, Sutcliffe JG (1988) p1B15: a cDNA clone of the rat mRNA encoding cyclophilin. DNA 1:231-237.

de Bilbao F, Giannakopoulos P, Srinivasan A, Dubois-Dauphin M (2000) In vivo study of motoneuron death induced by nerve injury in mice deficient in the caspase 1/interleukin-1 beta-converting enzyme. Neuroscience 98:573-583.

deLapeyrière O, Henderson CE (1997) Motoneuron differentiation, survival and synaptogenesis. Curr Opin Genet Dev 7:642-650.

Dubois-Dauphin M, Frankowski H, Tsujimoto Y, Huarte J, Martinou JC (1994) Neonatal motoneurons overexpressing the bcl-2 protooncogene in transgenic mice are protected from axotomy-induced cell death. Proc Natl Acad Sci USA 91:3309-3313. 
Eckenstein F (1988) Transient expression of NGF-receptor-like immunoreactivity in postnatal rat brain and spinal cord. Brain Res 446:149-154.

Elde R, Cao YH, Cintra A, Brelje TC, Pelto-Huikko M, Junttila T, Fuxe K, Pettersson RF, Hokfelt T (1991) Prominent expression of acidic fibroblast growth factor in motor and sensory neurons. Neuron 7:349-364.

Ericson J, Thor S, Edlund T, Jessell TM, Yamada T (1992) Early stages of motor neuron differentiation revealed by expression of homeobox gene Islet-1. Science 256:1555-1560.

Ernfors P, Henschen A, Olson L, Persson H (1989) Expression of nerve growth factor receptor mRNA is developmentally regulated and increased after axotomy in rat spinal cord motoneurons. Neuron 2:1605-1613.

Farlie PG, Dringen R, Rees SM, Kannourakis G, Bernard O (1995) bcl-2 transgene expression can protect neurons against developmental and induced cell death. Proc Natl Acad Sci USA 92:4397-4401.

Flanders KC, Ludecke G, Engels S, Cissel DS, Roberts AB, Kondaiah P, Lafyatis R, Sporn MB, Unsicker K (1991) Localization and actions of transforming growth factor-betas in the embryonic nervous system. Development 113:183-191.

Garces A, Nishimune H, Philippe JM, Pettmann B, deLapeyrière O (2000) FGF9: a motoneuron survival factor expressed by medial thoracic and sacral motoneurons. J Neurosci Res 60:1-9.

Gassmann M, Lemke G (1997) Neuregulins and neuregulin receptors in neural development. Curr Opin Neurobiol 7:87-92.

Gentry LE, Twardzik DR, Lim GJ, Ranchalis JE, Lee DC (1987) Expression and characterization of transforming growth factor alpha precursor protein in transfected mammalian cells. Mol Cel Biol 7:1585-1591.

Gouin A, Bloch-Gallego E, Tanaka H, Rosenthal A, Henderson CE (1996) Transforming growth factor-beta 3, glial cell line-derived neurotrophic factor, and fibroblast growth factor-2, act in different manners to promote motoneuron survival in vitro. J Neurosci Res 43:454-464.

Graus-Porta D, Beerli RR, Daly JM, Hynes NE (1997) ErbB-2, the preferred heterodimerization partner of all ErbB receptors, is a mediator of lateral signaling. EMBO J 16:1647-1655.

Hackel PO, Zwick E, Prenzel N, Ullrich A (1999) Epidermal growth factor receptors: critical mediators of multiple receptor pathways. Curr Opin Cell Biol 11:184-189.

Halse R, Rochford JJ, McCormack JG, Vandenheede JR, Hemmings BA, Yeaman SJ (1999) Control of glycogen synthesis in cultured human muscle cells. J Biol Chem 274:776-780.

Hanson Jr MG, Shen S, Wiemelt AP, McMorris FA, Barres BA (1998) Cyclic AMP elevation is sufficient to promote the survival of spinal motor neurons in vitro. J Neurosci 18:7361-7371.

Hayase Y, Higashiyama S, Sasahara M, Amano S, Nakagawa T, Taniguchi N, Hazama F (1998) Expression of heparin-binding epidermal growth factor-like growth factor in rat brain. Brain Res 784:163-178.

Henderson C, Camu W, Mettling C, Gouin A, Poulsen K, Karihaloo M, Rullamas J, Evans TO, McMahon SB, Armanini MP, Berkemeier L, Phillips HS, Rosenthal A (1993) Neurotrophins promote motor neuron survival and are present in embryonic limb bud. Nature 363:266-270.

Henderson CE, Phillips HS, Pollock RA, Davies AM, Lemeulle C, Armanini M, Simmons L, Moffet B, Vandlen RA, Simpson LC, Moffet B, Vandlen RA, Koliatsos VE, Rosenthal A (1994) GDNF: a potent survival factor for motoneurons present in peripheral nerve and muscle. Science 266:1062-1064.

Houenou LJ, Li L, Lo AC, Yan Q, Oppenheim RW (1994) Naturally occurring and axotomy-induced motoneuron death and its prevention by neurotrophic agents: a comparison between chick and mouse. Prog Brain Res102:217-226.

Jhappan C, Stahle C, Harkins RN, Fausto N, Smith GH, Merlino GT (1990) TGF $\alpha$ overexpression in transgenic mice induces liver neoplasia and abnormal development of the mammary gland and pancreas. Cell 61:1137-1146.

Junier MP (2000) What role(s) for TGFalpha in the central nervous system? Prog Neurobiol 62:443-473.

Junier MP, Ma YJ, Costa MA, Hoffman G, Hill DF, Ojeda SR (1991) Transforming growth factor $\alpha$ contributes to the mechanism by which hypothalamic injury induces precocious puberty. Proc Natl Acad Sci USA 88:9743-9747.

Junier MP, Hill DF, Costa ME, Felder SE, Ojeda SR (1993) Hypothalamic lesions that induce female precocious puberty activate glial expression of the epidermal growth factor receptor gene: differential regulation of alternatively spliced transcripts. J Neurosci 13:703-713.

Junier MP, Coulpier M, Le Forestier N, Cadusseau J, Suzuki F, Peschanski M, Dreyfus PA (1994) Transforming growth factor alpha (TGFalpha) expression in degenerating motoneurons of the murine mutant wobbler: a neuronal signal for astrogliosis? J Neurosci 14:4206-4216.

Junier MP, Legendre P, Esguerra CV, Tinel M, Coulpier M, Dreyfus PA, Bahr M (1998) Regulation of growth factor gene expression in degenerating motoneurons of the murine mutant wobbler: a cellular patchsampling/RT-PCR study. Mol Cell Neurosci 12:168-177.
Kanda T, Iwasaki T, Nakamura S, Ueki A, Kurokawa T, Ikeda K, Mizusawa H (1999) FGF-9 is an autocrine/paracrine neurotrophic substance for spinal motoneurons. Int J Dev Neurosci 17:191-200.

Kato AC, Lindsay RM (1994) Overlapping and additive effects of neurotrophins and CNTF on cultured human spinal cord neurons. Exp Neurol 130:196-201.

Koliatsos VE, Clatterbuck RE, Winslow JW, Cayouette MH, Price DL (1993) Evidence that brain-derived neurotrophic factor is a trophic factor for motor neurons in vivo. Neuron 10:359-367.

Kornblum HI, Hussain RJ, Bronstein JM, Gall CM, Lee DC, Seroogy KB (1997) Prenatal ontogeny of the epidermal growth factor receptor and its ligand, transforming growth factor alpha, in the rat brain. J Comp Neurol 380:243-261.

Kornblum HI, Hussain R, Wiesen J, Miettinen P, Zurcher SD, Chow K, Derynck R, Werb Z (1998) Abnormal astrocyte development and neuronal death in mice lacking the epidermal growth factor receptor. J Neurosci Res 53:697-717.

Krieglstein K, Henheik P, Farkas L, Jaszai J, Galter D, Krohn K, Unsicker K (1998) Glial cell line-derived neurotrophic factor requires transforming growth factor-beta for exerting its full neurotrophic potential on peripheral and CNS neurons. J Neurosci 18:9822-9834.

Kuzis K, Coffin JD, Eckenstein FP (1999) Time course and age dependence of motor neuron death following facial nerve crush injury: role of fibroblast growth factor. Exp Neurol 157:77-87.

Lee DC, Fenton SE, Berkowitz EA, Hissong MA (1995) Transforming growth factor alpha: expression, regulation, and biological activities. Pharmacol Rev 47:51-85.

Lenferink AE, Pinkas-Kramarski R, van de Poll ML, van Vugt MJ, Klapper LN, Tzahar E, Waterman H, Sela M, van Zoelen EJ, Yarden Y (1998) Differential endocytic routing of homo- and hetero-dimeric ErbB tyrosine kinases confers signaling superiority to receptor heterodimers. EMBO J 17:3385-3397.

Lim RW, Hauschka SD (1984) EGF responsiveness and receptor regulation in normal and differentiation-defective mouse myoblasts. Dev Biol 105:48-58.

Lisovoski F, Blot S, Lacombe C, Bellier JP, Dreyfus PA, Junier MP (1997) Transforming growth factor alpha expression as a response of murine motor neurons to axonal injury and mutation-induced degeneration. J Neuropath Exp Neurol 56:459-471.

Luetteke NC, Qiu TH, Peiffer RL, Smithies O, Lee DC (1993) TGF- $\alpha$ deficiency results in hair follicle and eye abnormalities in targeted and waved-1 mice. Cell 73:263-278.

Mann GB, Fowler KJ, Gabriel A, Nice EC, Williams RL, Dunn AR (1993) Mice with a null mutation of the TGF $\alpha$ gene have abnormal skin architecture, wavy hair, and curly whiskers and often develop corneal inflammation. Cell 73:249-261.

Martinou JC, Dubois-Dauphin M, Staple JK, Rodriguez I, Frankowski H, Missotten M, Albertini P, Talabot D, Catsicas S, Pietra C, Huarte J (1994) Overexpression of BCL-2 in transgenic mice protects neurons from naturally occurring cell death and experimental ischemia. Neuron 13:1017-1030.

Miettinen PJ, Berger JE, Meneses J, Phung Y, Pedersen RA, Werb Z, Derynck R (1995) Epithelial immaturity and multiorgan failure in mice lacking epidermal growth factor receptor. Nature 376:337-341.

Mirsky R, Jessen KR (1999) The neurobiology of Schwann cells. Brain Pathol 9:293-311.

Olwin BB, Hauschka SD (1988) Cell surface fibroblast growth factor and epidermal growth factor receptors are permanently lost during skeletal muscle terminal differentiation in culture. $\mathbf{J}$ Cell Biol 107:761-769.

Oppenheim RW (1996) Neurotrophic survival molecules for motoneurons: an embarrassment of riches. Neuron 17:195-197.

Penkowa M, Nielsen H, Hidalgo J, Bernth N, Moos T (1999) Distribution of metallothionein I + II and vesicular zinc in the developing central nervous system: correlative study in the rat. J Comp Neurol 412:303-318.

Petch LA, Harris J, Raymond VW, Blasband A, Lee DC, Earp HS (1990) A truncated, secreted form of the epidermal growth factor receptor is encoded by an alternatively spliced transcript in normal rat tissue. Mol Cell Biol 10:2973-2982.

Phelps PE, Barber RP, Brennan LA, Maines VM, Salvaterra PM, Vaughn JE (1990) Embryonic development of four different subsets of cholinergic neurons in rat cervical spinal cord. J Comp Neurol 291:9-26.

Rabchevsky AG, Weinitz JM, Coulpier M, Fages C, Tinel M, Junier MP (1998) A role for transforming growth factor alpha as an inducer of astrogliosis. J Neurosci 18:10541-10552.

Sandrock Jr AW, Dryer SE, Rosen KM, Gozani SN, Kramer R, Theill LE, Fischbach GD (1997) Maintenance of acetylcholine receptor number by neuregulins at the neuromuscular junction in vivo. Science 276:599-603.

Sastry SK, Lakonishok M, Thomas DA, Muschler J, Horwitz AF (1996) Integrin alpha subunit ratios, cytoplasmic domains, and growth factor synergy regulate muscle proliferation and differentiation. $\mathrm{J}$ Cell Biol 133:169-184

Schecterson LC, Bothwell M (1992) Novel roles for neurotrophins are 
suggested by BDNF and NT-3 mRNA expression in developing neurons. Neuron 9:449-463.

Sendtner M, Kreutzberg GW, Thoenen H (1990) Ciliary neurotrophic factor prevents the degeneration of motor neurons after axotomy. Nature 345:440-441.

Sendtner M, Holtmann B, Kolbeck R, Thoenen H, Barde YA (1992) Brain-derived neurotrophic factor prevents the death of motoneurons in newborn rats after nerve section. Nature 360:757-759.

Sendtner M, Holtmann B, Hughes RA (1996) The response of motoneurons to neurotrophins. Neurochem Res 21:831-841.

Sibilia M, Wagner EF (1995) Strain-dependent epithelial defects in mice lacking the EGF receptor. Science 269:234-238.

Sibilia M, Steinbach JP, Stingl L, Aguzzi A, Wagner EF (1998) A strainindependent postnatal neurodegeneration in mice lacking the EGF receptor. EMBO J 17:719-731.

Threadgill DW, Dlugosz AA, Hansen LA, Tennenbaum T, Lichti U, Yee D, LaMantia C, Mourton T, Herrup K, Harris RC, Barnard JA, Yuspa SH, Coffey RJ, Magnuson T (1995) Targeted disruption of mouse EGF receptor: effect of genetic background on mutant phenotype. Science 269:230-234.

Todaro GJ, Fryling C, De Larco JE (1980) Transforming growth factors produced by certain human tumor cells: polypeptides that interact with epidermal growth factor receptors. Proc Natl Acad Sci USA 77:5258-5262.

Toma JG, Pareek S, Barker P, Mathew TC, Murphy RA, Acheson A, Miller FD (1992) Spatiotemporal increases in epidermal growth factor receptors following peripheral nerve injury. J Neurosci 12:2504-2515.

Vanderluit JL, McPhail LT, Fernandes KJ, McBride CB, Huguenot C, Roy S, Robertson GS, Nicholson DW, Tetzlaff W (2000) Caspase-3 is activated following axotomy of neonatal facial motoneurons and caspase-3 gene deletion delays axotomy-induced cell death in rodents. Eur J Neurosci 12:3469-3480.

Vejsada R, Sagot Y, Kato AC (1995) Quantitative comparison of the transient rescue effects of neurotrophic factors on axotomized motoneurons in vivo. Eur J Neurosci 7:108-115.

Waalkes MP, Klaassen CD (1984) Postnatal ontogeny of metallothionein in various organs of the rat. Toxicol Appl Pharmacol 74:314-320.

Yan Q, Johnson Jr EM (1988) An immunohistochemical study of the nerve growth factor receptor in developing rats. J Neurosci 8:3481-3498.

Yan Q, Elliott J, Snider WD (1992) Brain-derived neurotrophic factor rescues spinal motor neurons from axotomy-induced cell death. Nature 360:753-755.

Yan Q, Matheson C, Lopez OT (1995) In vivo neurotrophic effects of GDNF on neonatal and adult facial motor neurons. Nature 373:341-344. 